\title{
Stimulatory effect of insulin-like growth factor I and epidermal growth factor on the maturation of rabbit oocytes in vitro
}

\author{
P. L. Lorenzo ${ }^{1}$, P. G. Rebollar ${ }^{2}$, M. J. Illera ${ }^{\mathrm{I}}$, J. C. Illera ${ }^{\mathrm{I}}$, M. Illera ${ }^{\mathrm{I}}$ and \\ J. M. R. Alvariño ${ }^{2}$ \\ ${ }^{1}$ Departamento de Fisiología Animal, Facultad de Veterinaria, Universidad Complutense de Madrid, \\ Ciudad Universitaria and ${ }^{2}$ Departamento de Producción Animal, ETSI Agrónomos, Universidad \\ Politécnica de Madrid, Ciudad Universitaria, 28040 Madrid, Spain
}

\begin{abstract}
The effects of different combinations of epidermal growth factor (EGF) and insulin-like growth factor I (IGF-I) on cumulus expansion and meiotic maturation were examined in rabbit oocytes. Selected rabbit follicular oocytes were matured in vitro and were classified as cumulus-oocyte complexes or denuded oocytes. They were cultured in TCM 199, and were treated with growth factors at different concentrations: EGF at 0, 1, 10, 50 and $100 \mathrm{ng} \mathrm{ml}^{-1}$, IGF-I at 0,50, 100 and $200 \mathrm{ng} \mathrm{ml}^{-1}$ and EGF plus IGF-I at $10+50 ; 10+100$; $50+50$ and $50+100 \mathrm{ng} \mathrm{ml}^{-1}$, respectively. After $6 \mathrm{~h}$ of culture, the oocytes were assessed for nuclear maturation and after $16 \mathrm{~h}$ of culture, for cumulus expansion and maturation stage. After culture for $6 \mathrm{~h}$, the incidence of germinal vesicle breakdown was higher $(P<0.05)$ in all of the growth factor treatments tested compared with controls. After culture for $16 \mathrm{~h}$, EGF enhanced the incidence of cumulus expansion at all of the concentrations tested. Cumulus expansion was greatest with $50 \mathrm{mg} \mathrm{EGF} \mathrm{ml}^{-1}$ plus $100 \mathrm{ng} \mathrm{IGF-I} \mathrm{ml}^{-1}$ $(72.0 \%$ versus $2.4 \%$ in controls). Treatment with IGF-I significantly increased $(P<0.05)$ the incidence of metaphase II stage, and maximum stimulation occurred at $100 \mathrm{ng}$ IGF-I ml ${ }^{-1}$ ( $84.5 \%$ versus $31.1 \%$ in controls). However, IGF-I did not affect cumulus expansion. When denuded oocytes were used, no positive effects on nuclear maturation rates were observed for any treatment. These results suggest that: (1) EGF, either alone or with IGF-I, stimulates cumulus expansion; (2) the addition of IGF-I or EGF plus IGF-I significantly enhances nuclear maturation in immature rabbit oocytes; and (3) this effect is mediated by the presence of cumulus cells.
\end{abstract}

\section{Introduction}

Mammalian oocytes mature in vivo at the time of the preovulation gonadotrophin surge, but can also mature in vitro in a suitable medium (Edwards, 1965). Maturation depends on the interaction of many factors and enables oocyte development to reach metaphase II. Implementation of technologies dependent on maturation in vitro requires knowledge and understanding of factors determining the meiotic and developmental potential of oocytes under conditions in vitro.

Gonadotrophins are the primary regulators of nuclear maturation in these oocytes. However, more recent observations imply that gonadotrophins are only part of the complex sequence of factors, such as growth factors, that regulate ovarian function (Tonetta and DiZerega, 1989). Epidermal growth factor (EGF) stimulates proliferation of ovarian granulosa cells in various species (Gospodarovicz and Bialeki, 1979; May et al., 1987), modulates differentiation of granulosa cells (Hsueh et al., 1981), and in women stimulates the growth of small follicles (Westergaard et al., 1990). Insulin-like growth

Received 27 November 1995
factor-I (IGF-I) is a potent mitogen for granulosa cells (Hernández et al., 1988), even in the absence of FSH (Veldhuis et al., 1986), and acts as a biological amplifier of the action of FSH in the ovary (Hsu and Hammond, 1987).

The regulation of oocyte maturation by growth factors in animal species such as mice (Brucker et al., 1991), rats (Feng et al., 1988), pigs (Reed et al., 1993; Ding and Foxcroft, 1994) and cattle (Harper and Brackett, 1993; Lorenzo et al., 1994) has been described. Studies in vitro with EGF showed the induction of germinal vesicle breakdown in cumulus cell-enclosed mouse oocytes maintained in meiotic arrest with purines, dibutyrylAMP, or the phosphodiesterase inhibitor IBMX (Downs $e t$ al., 1988; Downs, 1989). It appears that EGF, like LH, promotes oocyte maturation either by disruption of its communication with cumulus cells (Dekel and Sherizly, 1985) or that it creates a positive maturation signal (Downs, 1989). However, IGF-I stimulates maturation in Xenopus oocytes (Hainaut et al., 1991), enhances bovine oocyte maturation and fertilization in vitro (Lorenzo et al., 1993), and improves the quality of bovine embryos (Herlerr et al, 1992). It is possible that there is a relationship between IGF-I and oocyte maturation, particularly as high concentrations of IGF-I were found in the cumulus 
oophorus of rats (Oliver et al., 1989). Moreover, in several studies immunoreactive IGF-I was localized in the thecainterstitial compartment and in the cumulus cells surrounding the oocyte (Balboni et al., 1987). However, there is no information about growth factor-induced regulation of rabbit oocyte maturation. Rabbit oocytes are widely used as an in vitro model in experimental procedures on mammalian oocytes and embryos (Kaufmann et al., 1990; Yoshimura et al., 1992).

The aim of the present study was to establish whether EGF and IGF-I alone or in combination, added to maturation media, without the addition of exogenous hormones, enhance the cumulus expansion and the maturation rate of rabbit oocytes in vitro. The results obtained may serve to shed light on some physiological functions of these growth factors with respect to oocyte maturation.

\section{Materials and Methods}

All media and reagents were purchased from Sigma Chemical Co. (St Louis, MO) except IGF-I (Boehringer Mannheim $\mathrm{GmbH}$, Mannheim). The medium used for washing and maturation of oocytes consisted of TCM 199 with Earle's salts, modified by the addition of L-glutamine, sodium bicarbonate, glucose, sodium pyruvate and gentamicin sulfate as described by Arellano et al. (1993). This medium is subsequently referred to as TCM 199. Stock solutions of growth factors were diluted and added to TCM 199 for maturation culture as appropriate. They were reconstituted in PBS solution (without glucose) containing $3 \mathrm{mg} \mathrm{BSA} \mathrm{ml}{ }^{-1}$, and stored at $-20^{\circ} \mathrm{C}$ until used. The final concentration of $\mathrm{BSA}$ in the maturation medium was $0.003 \%(\mathrm{w} / \mathrm{v})$. Human recombinant EGF, IGF and EGF + IGF-I in various combinations were added to the maturation media as described below.

Sexually mature New Zealand White $\times$ Californian does $(2.5-3.5 \mathrm{~kg}$ body mass) were used as ovary donors. Animals used in this study were treated according to the CEE Council Directive $(86 / 609$, 1986) for the Care of Experimental Animals. They were housed individually in metal cages $(32 \mathrm{~cm} \times 52 \mathrm{~cm}$ ) on perforated sheets in air-conditioned rooms $\left(25^{\circ} \mathrm{C}\right.$, $45 \%$ relative humidity); under a $16 \mathrm{~h}$ light: $8 \mathrm{~h}$ dark cycle (average light intensity, $45 \pm 10 \mathrm{~lx}$ ). Artificial lights were on from $08.00 \mathrm{~h}$ to $24.00 \mathrm{~h}$. Pelleted commercial diet (Lab Rabbit Chow, Purina Mills Inc.: $16.2 \%$ protein, $2.5 \%$ fat and $13.5 \%$ crude fibre) was restricted to about $125 \mathrm{~g} \mathrm{day}^{-1}$, and water was supplied ad libitum. Animals were kept in these conditions for at least 16 days and they were then killed at an abattoir and their ovaries removed. The ovaries were transported in PBS (supplemented with $100 \mu \mathrm{g}$ penicillin $\mathrm{ml}^{-1}$ and $50 \mu \mathrm{g}$ streptomycin $\mathrm{ml}^{-1}$ ) to the laboratory within $2 \mathrm{~h}$ of death, and were then placed in $5 \mathrm{ml}$ TCM 199 in $60 \mathrm{~mm}$ Petri dishes. Ovaries were excluded from further study if they appeared to be immature or if $50 \%$ or more of the surface follicles appeared haemorrhagic. Selected follicles (> $1 \mathrm{~mm}$ in diameter) were sliced under a dissecting microscope with an iris knife to release the follicular contents. Follicles smaller than $1 \mathrm{~mm}$ in diameter contain oocytes not competent to achieve meiosis (Jelinkova ef al., 1994). Collected oocytes were kept in $35 \mathrm{~mm}$, sterile, Petri dishes containing TCM 199 medium, and were washed five times before culture. According to predefined criteria (Lorenzo et al., 1994), selected cumulus-oocytes were divided into cumulus-oocyte complexes (with intact and unexpanded cumulus) or denuded oocytes (without layers of cumulus cells), placed under $1.0 \mathrm{ml}$ TCM 199 medium and cultured at $37^{\circ} \mathrm{C}$ in $5 \% \mathrm{CO}_{2}$ in air and $100 \%$ humidity for $16 \mathrm{~h}$. The oocytes collected were pooled and assigned to treatment groups at random.

\section{Assessment of cumulus expansion}

Cumulus-oocyte complexes were evaluated after culture for $16 \mathrm{~h}$ to assess the effect of growth factors on cumulus expansion. Cumulus expansion was scored based on the subjective scale of 0 to 3 , in which 0 indicates no detectable response; 1 shows the minimum observable response; 2 indicates partial expansion, with more than half of the cumulus expanded; and 3 shows full expansion, where all layers of cumulus cells have expanded, including those closest to the oocyte.

\section{Assessment of nuclear maturation}

At the end of $6 \mathrm{~h}$ and $16 \mathrm{~h}$ of culture, oocytes were fixed and stained to ascertain the influence of growth factors on nuclear maturation, and the effect of the presence or absence of cumulus cells surrounding the oocyte. Both cumulus-oocyte complexes and denuded oocytes were used. Cumulus-oocyte complexes were placed in PBS solution containing 200 iu hyaluronidase $\mathrm{ml}^{-1}$. Cumulus cells were removed mechanically by repeated aspiration with a fine-bore pipette. The oocytes were then pipetted onto a slide. A coverslip, spotted with a paraffin wax-vaseline (10:1) mixture at each corner, was placed directly over the centre of the drop containing the oocytes. Fixation of oocytes was carried out by placing the slides in acetic acid:ethanol (1:3) for $24 \mathrm{~h}$, and staining with aceto-orcein ( $1 \%$ orcein in $60 \%$ acetic acid) for 5 min. Nuclear maturation was evaluated under a phase contrast microscope at $\times 200$ and $\times 500$ magnification, and was expressed as the percentage of oocytes that had achieved metaphase II. Oocytes were also assessed according to the status of the germinal vesicle.

\section{Design and analysis of experiments}

In Expt 1, cumulus-oocyte complexes and denuded oocytes were cultured in vitro with different concentrations of EGF ranging from 1 to $100 \mathrm{ng} \mathrm{ml}^{-1}$, while in Expt 2, oocytes were cultured with 50, 100 and $200 \mathrm{ng}$ IGF-I ml ${ }^{-1}$, and were compared with controls. In Expt 3, the effect of different combinations of EGF and IGF-I (10 and $50 \mathrm{ng} \mathrm{EGF} \mathrm{ml}^{-1}$, and 50 and $100 \mathrm{ng} \mathrm{IGF-I} \mathrm{ml}^{-1}$ ) on maturation in vitro was investigated. Cumulus expansion in the cumulus-oocyte complexes, and the status of the germinal vesicle and metaphase II stages in both groups of oocyte (complexes and denuded), were used as endpoint parameters for assessing the effect of the growth factors on rabbit oocyte expansion and nuclear maturation in vitro. Each experiment was replicated nine times. Control oocytes (usually fewer oocytes were used in control groups 
than in treatment groups) were handled in the same way as the treatment oocytes, but without addition of growth factors.

\section{Statistical analyses}

Statistical analysis of endpoints was carried out with pooled data using the Biomedical Data Program (BMDP, Dixon et al., 1990). Mean values were subjected to analysis of variance using the $7 \mathrm{~d}$ procedure (one- and two-way ANOVA) of BMDP. When the $7 \mathrm{~d}$ procedure revealed a significant treatment effect, the means were analysed by pairwise $t$ test and Bonferroni post-test to ascertain statistical differences between treatments. A $P$ value less than 0.05 was accepted as significant.

\section{Results}

Experiment 1: effects of EGF on cumulus expansion and oocyte maturation

The addition of EGF to oocytes cultured for $6 \mathrm{~h}$ stimulated germinal vesicle breakdown (GVBD) in a dose-dependent manner (Table 1). A significantly higher proportion of oocytes exhibited GVBD when cultured with $50 \mathrm{ng} \mathrm{EGF} \mathrm{ml}^{-1}(62.9 \%)$ compared with those cultured in the control medium $(27.2 \%)$. There was a significant increase in the number of oocytes undergoing metaphase II after $16 \mathrm{~h}$ of culture compared with control oocytes for all concentrations of EGF used, and $10 \mathrm{ng}$ EGF $\mathrm{ml}^{-1}$ was the most effective $(73.5 \%)$. Results obtained revealed significant differences $(P<0.05)$ in the proportions of complexes undergoing cumulus expansion (partial and full) between the control medium and all concentrations of EGF used (Table 1). The highest percentages of full cumulus expansion observed were $26.1 \%$ and $28.3 \%$, obtained with 10 and $50 \mathrm{ng}$ EGF $\mathrm{ml}^{-1}$, respectively (data not shown). These values are significantly different compared with untreated control $(P<0.05)$ but not with the other concentrations of EGF,

\section{Experiment 2: effects of IGF-I on cumulus expansion and oocyte maturation}

After $6 \mathrm{~h}$ of culture, the addition of IGF-I significantly stimulated GVBD $(P<0.05)$ compared with the controls for all concentrations used (Table 2). After $16 \mathrm{~h}$ of culture, no significant effect on the proportion of cumulus-oocyte complexes undergoing cumulus expansion was observed after treatment with IGF-I $(4.8 \%, 5.6 \%$ and $4.9 \%$, for 50,100 and $200 \mathrm{ng}$ IGF-I ml ${ }^{-1}$, respectively) compared with control treatment (TCM 199, 2.2\%). However, significant differences $(P<0.05)$ were observed in the proportion of oocytes reaching metaphase II between the control (31.1\%) and 50, 100 and $200 \mathrm{ng} \mathrm{ml}^{-1}$ IGF-I treatment groups $(83.8 \%, 84.5 \%$ and $61.7 \%$, respectively).

Experiment 3: combined effects of EGF and IGF-I on cumulus expansion and oocyte maturation

Those concentrations which produced the greatest effects in the first two experiments ( 10 and $50 \mathrm{ng} \mathrm{EGF} \mathrm{ml}^{-1}$, and 50 and
$100 \mathrm{ng}$ IGF-I ml ${ }^{-1}$ ) were used in this experiment. When EGF was used in conjunction with IGF-I, the number of complexes undergoing cumulus expansion (partial and full) was significantly greater than that observed in the controls, or when IGF-I was used alone $(P<0.01)$ (Table 3 ). However, the highest nuclear maturation rates obtained when EGF was used in combination with IGF-I $\left(10+100\right.$ and $50+100 \mathrm{ng} \mathrm{ml}^{-1}$ of EGF and IGF-I, respectively) were less, although not significantly so $(P>0.05)$, than those obtained with IGF-I alone.

Finally, there were no significant differences in the rate of maturation (neither at germinal vesicle breakdown after $6 \mathrm{~h}$ of culture nor at metaphase II stage after $16 \mathrm{~h}$ of culture, respectively) for denuded oocytes among the growth factor treatments used (Table 4). The incidence of degeneration in denuded oocytes, at $6 \mathrm{~h}$ and $16 \mathrm{~h}$ of culture, was not significantly reduced by the addition of growth factors (range: $29.8-21.0 \%$, data not shown), contrary to the results for the cumulus-oocyte complexes (Tables $I$ to 3 ).

\section{Discussion}

Cumulus oophorus expansion in mammalian oocytes occurs in response to an ever-changing milieu of gonadotrophins, growth factors, steroids, factors secreted by the oocyte and other unknown molecules (Buccione et al., 1990). These compounds could be contributing to maturational changes that occur in the oocyte mediated by intracellular messengers such as cAMP, calmodulin or diacylglycerol (Gonçalves and Graves, 1992). The expansion criterion adopted in the present work was similar to that used by other authors (Downs, 1989; Buccione et al., 1990; Harper and Brackett, 1993). The most successful in vitro maturation systems used fetal serum or oestrous or pro-oestrous serum to optimize development of oocytes (Schellander et al., 1990). Serum is a highly complex combination of components including proteins, fatty acids, vitamins, hormones, trace elements and growth factors. By using a practically serum-free media for the in vitro maturation in the work presented here, it was possible to examine the relationship between growth factors and the regulation of nuclear maturation and cumulus expansion, while effectively ruling out the influence of unknown serum factor/s. The maturation medium used in the present study was supplemented with a BSA concentration $(0.003 \%)$ lower than that described by other authors as necessary to maintain cumulus expansion (3-6 $\mathrm{mg} \mathrm{ml}^{-1} \mathrm{w} / \mathrm{v}$, Leibfried-Rutledge et al., 1986). Therefore, the effects of the oocytes observed in the present study were presumably influenced by the growth factors tested.

The results presented here show that EGF enhances cumulus expansion in rabbit cumulus-oocyte complexes in the same way as demonstrated by Downs (1989) for rodent oocytes. However, the lesser effect of EGF on cumulus expansion compared with that seen in mouse oocytes may be due to the fact that, whereas recombinant human EGF was used in this study, homologous mouse EGF was used in Downs' study. Although IGF-I per se cannot promote effective cumulus expansion, this did not impair the maturation rate. Zhang et al. (1991) using IGF-I analogues such as insulin also recorded poor 


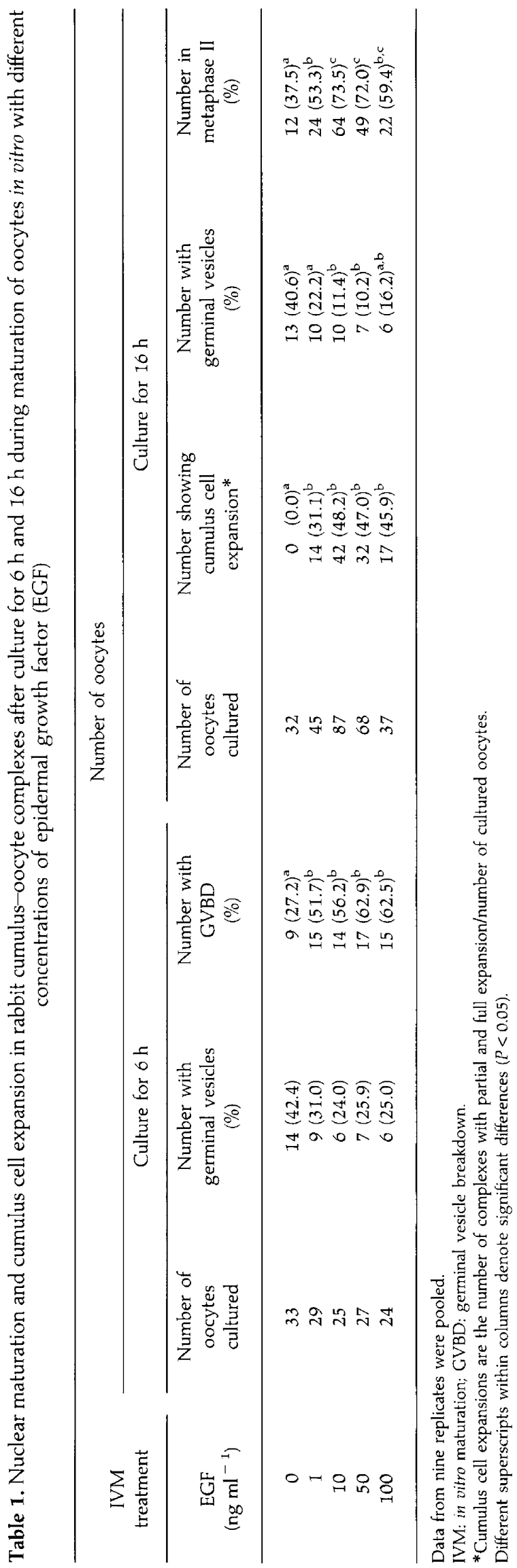




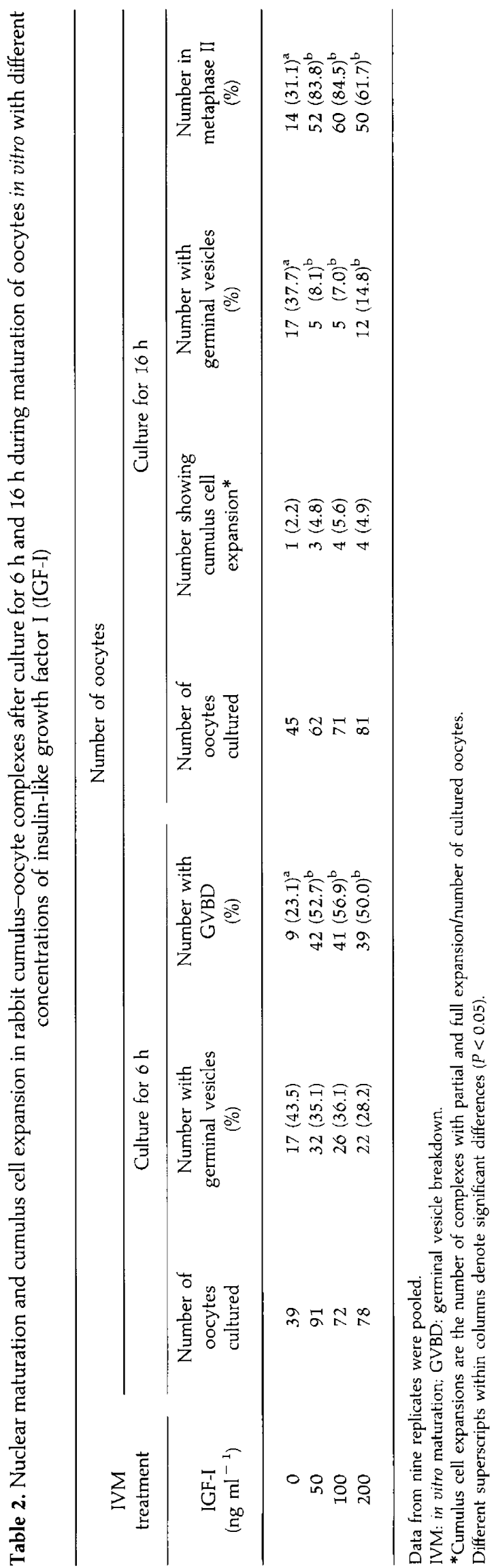




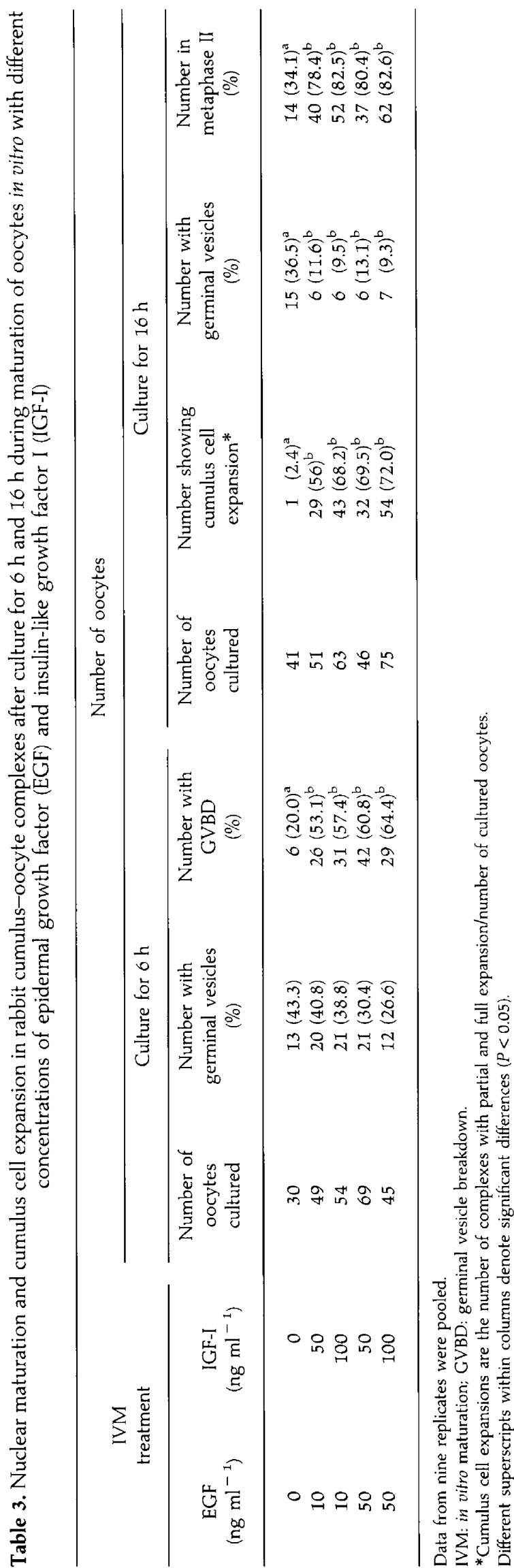


Table 4. Nuclear maturation in denuded oocytes from rabbits after culture for $6 \mathrm{~h}$ and $16 \mathrm{~h}$ during maturation of oocytes in vitro with different concentrations of epidermal growth factor (EGF) and/or insulin-like growth factor I (IGF-I)

\begin{tabular}{|c|c|c|c|c|c|}
\hline Treatment & $\begin{array}{l}\text { Concentration } \\
\left(\mathrm{ng} \mathrm{ml}^{-1}\right)\end{array}$ & $\begin{array}{l}\text { Number of } \\
\text { oocytes } \\
\text { cultured }\end{array}$ & $\begin{array}{c}\text { Number showing } \\
\text { GVBD } \\
\text { (after } 6 \mathrm{~h} \text { culture) } \\
(\%)\end{array}$ & $\begin{array}{l}\text { Number of } \\
\text { oocytes } \\
\text { cultured }\end{array}$ & $\begin{array}{c}\text { Number in } \\
\text { metaphase II } \\
\text { (after } 16 \mathrm{~h} \text { culture) } \\
(\%)\end{array}$ \\
\hline \multirow[t]{3}{*}{ EGF } & 0 & 30 & $7(23.3)$ & 21 & $6(28.5)$ \\
\hline & 1 & 31 & $8(25.8)$ & 25 & $6(24.0)$ \\
\hline & 100 & 31 & $9(29.0)$ & 20 & $6(30.0)$ \\
\hline \multirow[t]{4}{*}{ IGF-I } & 0 & 21 & $4(19.0)$ & 24 & $7(29.1)$ \\
\hline & 50 & 25 & $7(29.1)$ & 30 & $9(30.0)$ \\
\hline & 100 & 26 & $7(26.9)$ & 32 & $11(34.3)$ \\
\hline & 200 & 28 & $6(21.4)$ & 20 & $6(30.0)$ \\
\hline $\mathrm{EGF}+\mathrm{IGF}-\mathrm{I}$ & $50+100$ & 29 & $7(24.1)$ & 25 & $7(29.1)$ \\
\hline
\end{tabular}

Data from nine replicates were pooled.

GVBD: germinal vesicle breakdown.

There were no significant differences between treatments for any of the combinations or concentrations of growth factors used.

results for cumulus expansion. Since IGF-I receptors have been detected in granulosa cells and oocytes (Balboni et al., 1987), it is possible that the lack of significant effect on cumulus expansion may be due to IGF-I interfering with the production of an expansion factor produced by the oocyte itself (Buccione et al., 1990). However, the use of EGF and IGF-I combined induced slightly more cumulus expansion than with EGF alone, indicating an additive effect for these growth factors.

The present study confirmed that the growth factors tested stimulated nuclear maturation of rabbit oocytes in vitro in a dose-dependent manner, with the greatest effects at concentrations of $10-50 \mathrm{ng}^{\mathrm{EGF} \mathrm{ml}}{ }^{-1}$ and $100 \mathrm{ng}$ IGF-I ml ${ }^{-1}$. These factors, which have been shown to stimulate meiotic resumption in other species, had not been tested for their effect on oocyte maturation in rabbits. The highest percentages for EGF-induced nuclear maturation correspond to those obtained in rodent oocytes (Dekel and Sherizly, 1985; Downs, 1989). Downs et al. (1988) reported that EGF significantly increased cAMP concentrations in rodent oocytes, and that cAMP generated a positive maturation signal in cumulus cells in response to EGF stimulation. Such high rates of maturation can be attributed to the fact that the main agent involved in the inhibition of meiotic resumption in the oocytes of these species is the stimulation of CAMP-dependent protein kinase. However, in their response to protein kinase stimulation via cAMP accumulation, oocytes from the above species could differ from rabbit oocytes (Sirard et al., 1992) upon which EGF fails to act in the same way.

In contrast to observations in pigs (Reed et al., 1993) and cattle (Lorenzo et al., 1994), the highest results in nuclear maturation were achieved with IGF-I, which affected rabbit oocyte maturation in vitro to the same extent as EGF does in the above-mentioned species. IGF-I does not stimulate germinal vesicle breakdown in mouse oocytes (Downs, 1989) but does stimulate the resumption of meiosis in rat oocytes (Dekel and Sherizly, 1985). Hainaut et al. (1991) postulated that oocyte maturation with IGF-I is initiated upon activation of the membrane receptor for this growth factor and requires tyrosine dephosphorylation of $\mathrm{p} 34$, the kinase component of maturation promoting factor (MPF).

It has been demonstrated that these growth factors can be synthesized by the ovary (May et al., 1987). EGF and EGF-like substances have been found in pig $\left(13.6 \mathrm{ng} \mathrm{ml}^{-1}\right.$; Hsu et al., 1987), and human (0.60-31.3 $\mathrm{ng} \mathrm{ml}^{-1}$; Hoffmann et al., 1990) follicular fluids at concentrations similar to those used in the study reported here. Moreover, concentrations of IGF-I, similar to those used in the present study, have been detected in bovine and porcine follicular fluid (Hammond et al., 1988; Echternkamp et al., 1990). Receptors for IGF-I and EGF have been demonstrated in rat granulosa cells (Adashi et al., 1988; Rose et al., 1991), and specific binding of EGF to bovine and porcine cumulus cells has been observed (Fuginaga et al., 1992). Binding of growth factors to their receptors promotes the generation of signals and second messengers in the membrane and cytoplasm. These events may be involved in the signalling pathway leading to protein synthesis and phosphorylation, which would help to explain the physiological role of growth factors in oocyte maturation (Harper and Brackett, 1993).

The growth factors used in the study reported here enhanced maturation in cumulus-oocyte complexes but not in the denuded oocyte. This result is in agreement not only with the results observed in cattle (Sanbuissho et al., 1990; Lorenzo et al, 1993) and rodents (Deckel and Sherizly, 1985; Downs, 1989), but also with those obtained using transforming growth factor $\alpha$, which has similar effects to EGF in vitro (Brucker et al., 
1991), and binds to the same receptor species (Massague, 1983). A recent study in pig oocytes concluded that the action of EGF is mediated via the cumulus cells and gap junctions with the oocyte (Coskum and Lin, 1993). Since IGF-I or EGF could not enhance spontaneous maturation of denuded oocytes, either alone or together, our data seem to support the hypothesis that the growth factors act in the presence of the cumulus cells, via which a positive stimulus for maturation is transferred to the oocyte. This stimulatory signal(s) promotes oocyte maturation and can subsequently also disrupts oocyte communication with the cumulus cells.

Collectively, the present findings suggest that, at least in rabbits, the addition of IGF-I to the maturation medium results in more oocytes undergoing nuclear maturation than does the addition of EGF. No significant additive effect was observed when both growth factors were added to the maturation medium, as previously observed in bovine oocytes (Lorenzo et al., 1994), although the cumulus expansion rate was slightly enhanced when EGF plus IGF-I were added together. This result indicates that, at least in rabbits, EGF stimulation affects both cumulus cell expansion and nuclear oocyte maturation, while IGF action only significantly affects nuclear maturation; however, all these stimulatory actions are only possible in oocytes that are surrounded by cumulus cells.

Growth factors are now being considered as potential regulators of ovarian function and follicular development; they may be a 'key' factor in the regulation of intrafollicular oocyte maturation. It is also possible that EGF and IGF-I interact with gonadotrophins, steroids and other molecules to regulate oocyte follicular development in vivo. The study reported here provides evidence that EGF either alone or in conjunction with IGF-I stimulates cumulus expansion. The addition of IGF-I or EGF or both factors enhances nuclear maturation in immature rabbit oocytes in vitro and this effect is mediated by the presence of cumulus cells. These findings may serve to explain the mechanism of agents involved in the generation of signals regulating oocyte maturation processes.

The authors thank T. Calduch and M. L. Latorre for their assistance, and $\mathrm{H}$. Montero for taking care of the animals.

\section{References}

Adashi EY, Resnick CE, Hernández ER, Svoboda ME and van Wyk JS (1988) Characterization and regulation of a specific cell membrane receptor for somatomedin C/insulin-like growth factor-I in cultured rat granulosa cells Endocrinology 122 194-201

Arellano J, Illera MJ, Lorenzo P, Sánchez J, Silván G, Illera JC, Illera M and Petters RM (1993) Epidermal growth factor enhances porcine oocyte maturation in vitro in the absence of follicular fluid or hormones Theriogenology 39180

Balboni G, Vanelli GB, Barni T, Orlando C and Serio M (1987) Transferrin and somatomedin $\mathrm{C}$ receptors in the human ovary follicles Fertility and Sterility 48 796-801

Brucker C, Alexander NJ, Hodgen GD and Sandow BA (1991) Transforming growth factor- $\alpha$ augments meiotic maturation of cumulus cell-enclosed mouse oocytes Molecular Reproduction and Development 28 94-98

Buccione R, Vanderhyden BC, Caron PJ and Eppig JJ (1990) FSH-induced expansion of the mouse cumulus oophorus in vitro is dependent upon a specific factor(s) secreted by the oocyte Developmental Biology 138 16-25

Coskum $S$ and Lin YC (1993) Site of action of epidermal growth factor (EGF) on in vitro porcine oocyte maturation Endocrine Journal 1 87-91

Dekel N and Scherizly I (1985) Epidermal growth factor induces maturation of rat follicle-enclosed oocytes Endocrinology 116 512-516
Ding J and Foxcroft GR (1994) Epidermal growth factor enhances oocyte maturation in pigs Molecular Reproduction and Development 39 30-40

Dixon WJ, Brown MB, Engelman L, Hill MA and Jennrich RI (1990) BMDP Statistical Software Manual. University of California Press, Los Angeles

Downs SM (1989) Specificity of epidermal growth factor action on maturation of the murine oocyte and the cumulus oophorus in vitro Biology of Reproduction $41371-379$

Downs SM, Daniel SAJ and Eppig JJ (1988) Induction of maturation in cumulus cell-enclosed mouse oocytes by follicle-stimulating hormone and epidermal growth factor: evidence for a positive stimulus of somatic cell origin Journal of Experimental Zoology 245 86-96

Echternkamp SE, Spicer LJ, Gregory KE, Channing SF and Hammond JM (1990) Concentrations of insulin-like growth factor-I in blood and ovarian follicular fluid of cattle selected for twins Biology of Reproduction 43 8-14

Edwards RG (1965) Maturation in vitro of mouse, sheep, cow, pig, rhesus monkey and human ovarian oocytes Nature 208 349-351

Feng P, Catt KJ and Knecht $\mathbf{M}$ (1988) Transforming growth factor- $\beta$ stimulates meiotic maturation of the rat oocyte Endocrinology 122 181-186

Fuginaga H, Yamoto M, Nakano R and Shina K (1992) Epidermal growth factor binding site in porcine granulosa cells and their regulation by folliclestimulating hormone Biology of Reproduction 120 705-709

Gonçalves PB and Graves CN (1992) Interaction between CAMP, diacylglycerol and $\mathrm{Ca}^{2+}$-calmodulin pathways in regulation of cumulus expansion Biology of Reproduction 46 (Supplement 1) 69

Gospodarowicz D and Bialecki H (1979) Fibroblast and epidermal growth factors are mitogenic agents for cultured granulosa cells of rodent, porcine and human origin Endocrinology 104 757-764

Hainaut P, Giorgetti S, Kowlaski A, Ballotti R and Van Obberghen E (1991) Antibodies to phosphotyrosine injected into Xenopus laevis oocytes modulate maturation induced by insulin/IGF-I Experimental Cell Research 195 129-136

Hammond JM, Hsu CJ, Klindt J, Tsang BK and Downey BR (1988) Gonadotropins increase concentrations of immunoreactive insulin-like growth factor-I in porcine follicular fluid in vivo Biology of Reproduction 38 304-308

Harper MK and Brackett BJ (1993) Bovine blastocyst development after in vitro maturation in a defined medium with epidermal growth factor and low concentrations of gonadotrophins Biology of Reproduction 48 409-416

Herlerr A, Lucas-Hann A and Niemann A (1992) Effects of insulin-like growth factor-I on in vitro production of bovine embryos Theriogenology 37 $1213-1224$

Hernández ER, Resnick CE, Svoboda ME, Van Wyk JJ, Payne DW and Adashi EY (1988) Somatomedin-C/insulin-like growth factor I as an enhancer of androgen biosynthesis by cultured rat ovarian cells Endocrinology 122 $1603-1612$

Hoffmann GE, Scott RT Jr, Brzyski RG and Jones HW, Jr (1990) Immunoreactive epidermal growth factor concentration in follicular fluid obtained from in vitro fertilization Fertility and Sterility 54 303-307

Hsu C and Hammond JM (1987) Gonadotropins and estradiol stimulate immunoreactive insulin-like growth factor-I production by porcine cells in vitro Endocrinology 120 198-207

Hsu CJ, Holmes SD and Hammond JM (1987) Ovarian epidermal growth factor-like activity: concentrations in porcine follicular fluid during follicular enlargement Biochemical and Biophysical Research Communications 147 $242-247$

Hsueh AJW, Welsh TH and Jones BPC (1981) Inhibition of ovarian and testicular steroidogenesis by epidermal growth factor Endocrinology 108 2002-2004

Jelinkova L, Kubelka M, Motlik J and Guerrier P (1994) Chromatin condensation and histone $\mathrm{HI}$ kinase activity during growth and maturation of rabbits oocytes Molecular Reproduction and Development 37 210-215

Kaufmann RA, Savoy-Moore RT, Sacco A and Subramanian MG (1990) The effect of cocaine on oocyte development and the follicular microenvironment in the rabbit Fertility and Sterility $\mathbf{5 4} 921-926$

Leibfried-Rutledge ML, Critser ES and First NL (1986) Effect of fetal calf serum and bovine serum albumin on in vitro maturation and fertilization of bovine and hamster cumulus-oocyte complexes Biology of Reproduction 35 850-857

Lorenzo PL, Illera MJ, Sánchez J, Silván G, Illera JC and Illera M (1993) Bovine oocyte maturation and fertilization in vitro with growth factors and estrous cow serum Theriogenology 39262

Lorenzo PL, Illera MJ, Illera JC and Illera M (1994) Enhancement of cumulus expansion and nuclear maturation during bovine oocyte maturation in vitro 
by the addition of epidermal growth factor and insulin-like growth factor I Journal of Reproduction and Fertility 101 697-701

Massagué J (1983) Epidermal growth factor-like transforming growth factor II. Interaction with epidermal growth factor receptor in human placenta membranes and A431 cells Journal of Biological Chemistry 258 $13614-13620$

May JV, Buck PA and Shomberg DW (1987) Epidermal growth factor enhances ${ }^{125}$ iodo-follicle stimulating hormone binding by cultured porcine granulosa cells Endocrinology 120 2413-2420

Oliver JE, Aitman TJ, Powell JF, Wilson CA and Clayton RN (1989) Insulin-like growth factor I gene expression in the rat ovary is confined to the granulosa cells of developing follicles Endocrinology 124 2671-2679

Reed ML, Estrada JL, Illera MJ and Petters RM (1993) Effects of epidermal growth factor, insulin-like growth factor-l, and dialyzed porcine follicular fluid on porcine oocyte nuclear maturation in vitro Journal of Experimental Zoology 266 74-78

Rose TA, Fisher B and Sheffield LG (1991) Role of EGF in oocyte-somatic cell interactions in the bovine follicles Biology of Reproduction 44 (Supplement 1) 148

Sanbuissho A, Coskum S and Lin YC (1990) Stimulatory action of epidermal growth factor (EGF) on in vitro bovine oocyte maturation Assisted Reproductive Technology Andrology 1 143-153
Schellander K, Fuhrer G, Brackett BG, Korb H and Schleger W (1990) In vitro fertilization and cleavage of bovine oocytes matured in medium supplemented with estrous cow serum Theriogenology 33 477-485

Sirard MA, Coenen K and Bilodeau S (1992) Effects of fresh or cultured follicular fractions on meiotic resumption in bovine oocytes Theriogenology $3739-58$

Tonetta SA and DiZerega GS (1989) Intragonadal regulation of follicular maturation Endocrine Reviews 10 205-229

Veldhuis JD, Rodgers RJ and Furlanetto RW (1986) Synergistic actions of estradiol and the insulin-like growth factor somatomedin- $\mathrm{C}$ on swine ovarian (granulosa) cells Endocrinology 119 530-538

Westergaard LG, Andersen CY and Byskov AG (1990) Epidermal growth factor (EGF) in small antral ovarian follicles of pregnant women Journal of Endocrinology $127363-367$

Yoshimura Y, Nakamura Y, Ando M, Jinno M, Oda Y, Karube M, Koyama N and Nanno T (1992) Stimulatory role of cyclic adenosine monophosphate as a mediator of meiotic resumption in rabbit oocytes Endocrinology 131 $351-356$

Zhang L, Blakewood EG, Deninston RS and Godke RA (1991) The effect of insulin on maturation and development of in vitro-fertilized bovine oocytes Theriogenology 35301 